\title{
Gender and Higher Education in the Arab States
}

\section{André Elias Mazawi}

André Elias Mazawi teaches in the School of Education, Tel-Aviv University, Israel. Address: School of Education, Tel Aviv University, Ramat Aviv 69978, Israel.e-mail: mazawi@post.tau.ac.il

W omen's participation in higher education as students and faculty members remains a neglected dimension in understanding the substantial expansion of tertiary education in the Arab states. ${ }^{1}$ As higher education expanded, women's participation became differentially structured within a wider array of institutional settings. This has affected not only women's social visibility but also their ability to negotiate political power at various levels of action and in different fields.

On the eve of World War II, 10 universities were operating in all the Arab states. Half a century later, there were some 132 universities (half founded in the period 1980-1993), 136 university-level colleges or institutes, and 437 community colleges or diploma-granting technical institutes. ${ }^{2}$ The number of postsecondary students rose from about 3 million (out of a population of about 96 million) in the mid-1960s to about 2.5 million (out of a population of about 220 million) in the mid-1990s. Significant differences do still exist among states. In 1995, Lebanon, Jordan, and Kuwait each had over 2,300 students per 100,000 population, while Sudan, Yemen, and Oman each had less than 450. The remaining Arab states had rates ranging from 1,000 to 1,900 (UNESCO data).

\section{Enrollment Rates}

Women's enrollment accounts for an increasingly important portion of tertiary education expansion in many Arab states, particularly in the Gulf. Yet, their access is far from universal. Women come overwhelmingly from the urban middle and upper classes. Urban-rural disparities are also significant. In 1995, the gross higher education enrollment of the 18-to-23-year age group in the Arab states stood at 24.5 percent for men and 16.3 percent for women, with extreme differences between regions. In the Middle Eastern and North African (MENA) states, postsecondary student gender ratios ranged, in 1995, from .64 women for each man in Egypt, to .80 women for each man in Tunisia. In Jordan, the student gender ratio stood at .94 women for each man in 1995 compared to .45 women in 1970 . By contrast, in Yemen, the gender ratio is still as low as .14 women for each man. In comparison, in the Arabian Peninsular states from the 1970s onward, higher education expansion captured primarily a growing percentage of women while men sought higher education mainly abroad. By 1996, the student gender ratio was 1.18 women for each man in Saudi Arabia, 1.35 women in Kuwait, 1.87 women in Bahrain, 5.12 women in Qatar, and 6.08 women in the United Arab
Emirates (UAE). In fact, the expansion of local tertiary education institutions in the Arabian Peninsula was accompanied by a set of legal and social controls imposed on women's mobility and opportunities. Consequently, women have been confined largely to local institutions that do not always offer the range of disciplines available to men (e.g., engineering in Saudi Arabia). Thus, while MENA higher education institutions are usually coeducational, in the Arabian Peninsular states, institutions are, with some exceptions, gender specific. In these states, distance higher education programs emerged as a way of responding to women's growing demand for higher education while maintaining gender segregation.

\section{Arab State Feminism}

State policies seek to promote women's participation in higher education, as part of what has been termed "Arab state feminism," which endorses women's participation as part of state building and human capital formation, particularly in postindependence periods. ${ }^{3}$ These gender-specific enrollment policies enabled entrenched elites to redraw the distribution of social and political power and enhance regime legitimacy. It has been observed that within the sociocultural context of Gulf societies gender segregation, beyond its embedded discrimination, sometimes provides women with sheltered educational and occupational opportunities. ${ }^{4}$ These arrangements lessen or totally avoid competition with men and enable women to carve out their own professional and occupational spaces in gender-based occupations (e.g., medicine and education). Such a gendered division of opportunities has been called a "patriarchal gender contract." ${ }^{5}$ Thus beyond its modernizing effects, access to higher education in the Arab states also serves as a mechanism for social control and political cooptation. It reproduces existing class and gender stratification under differential opportunity structures available to gender groups or to distinct social classes.

\section{State policies seek to promote women's participation in higher education.}

\section{Women in Academia}

Just as in many other parts of the world, women's access to faculty positions in Arab States has been much more modest, with women often confined to lower-ranking faculty positions having more to do with teaching than with research. ${ }^{6}$ In some Arabian Peninsular states, however, gender-specific 
institutions have provided women with comparatively greater access to faculty membership. In 1996, women comprised about 30 percent of all faculty members in Bahrain, Qatar, and Saudi Arabia. By contrast, women experience fewer career opportunities than men in Jordan (18 percent), Kuwait (19 percent), Palestine (14 percent), Sudan (13 percent), Syria (16 percent), the UAE (9 percent), and Yemen (12 percent). In Egypt, Lebanon, Qatar, and Morocco women's share of faculty positions has remained quite stable since the 1980s, at between one-quarter and one-third of the total. Tunisia registered a significant increase, from 9 percent in 1980 to 30 percent in 1996 (UNESCO and World Bank data).

The factors suggested to explain the gender stratification of Arab faculty relate to the patriarchal characteristics of Arab societies and their effects on the subordination of women within higher education institutions. In a 1988 study of Arab academics, M'hammed Sabour found that the majority of faculty women in his sample came from middleand upper-class backgrounds. Still, their integration as equal members of an academic community continued to be subject to an array of male-imposed practices. ${ }^{7}$ Sabour has also written that "Arab academia is-through its aims, division of power, and process of decision-making - an almost entirely man-molded, man-minded, and man-oriented institution and place." 8

\section{In 1996, women comprised about 30 percent of all faculty members in Bahrain, Qatar, and Saudi Arabia.}

Women's presence within Arab higher education may, therefore, be described as stratified both horizontally and vertically. Horizontally, women tend to be located in distinct types of institutions and in gendered positions or fields of study. Vertically, women's mobility and social opportunities are significantly affected by their ascriptive status as women. Structurally, women have fewer opportunities to exchange acquired educational and professional capital into political and social power and prestige. This is due partly to the already quite weak and dependent position of the Arab academic vis-à-vis the established regime, a factor that further accentuates the institutional subordination of academic women. ${ }^{9}$ Gender stratification is also affected by limited occupational opportunity in economies already characterized by state centralism and deeply entrenched wealth inequalities. Women's subordinate position within higher education expresses the outcomes of this complex web of multidimensional inequalities, reproducing power structures within and between gender groups.

\section{A Critical Arena}

The institutional dimension of women's experience in Arab higher education also deserves attention. The workplace culture, though encompassing a variety of contexts, nonetheless affects gender identity, consciousness, and mobility. In spite of the lower returns they receive from higher education, women regard academic credentials as important for their emancipation. This belief further increases their enrollment rates, which in turn ultimately widens their unequal opportunities compared to men. In some instances, particularly in the Gulf, women have on average higher educational attainment levels than men. This disparity has not yet produced major changes in gender relations. Nonetheless, the intensity of conflicts reported surrounding women's social and political participation does show that women's movements are persistently striving with respect to affecting existing power relations.

In sum, the nexus between gender and higher education participation does not reflect just a culturally based problematic. The extreme gender variations observed suggest that higher education constitutes a critical arena where economy, politics, and the gendered construction of professional identity and power are constantly mediated. The issue of gender equality is basically a political one, strongly associated with the structure of the contemporary Arab state and its bases of power. This conclusion challenges Arab academic institutions to break with their reproductive role and eventually act as an avant-garde in the creation and dissemination of alternative gender and, by implication, civil relations.

\section{Notes}

1. The term "Arab states" refers to the following accredited members of the League of Arab States: Algeria, Bahrain, Egypt, Iraq, Jordan, Kuwait, Lebanon, Libya, Morocco, Oman, Palestine, Qatar, Saudi Arabia, Sudan, Syria, Tunisia, The United Arab Emirates, and Yemen.

2. S. Qasem, "The Arab states," World Science Report (Paris: UNESCO, 1996), 120.

3. Mervat Hatem, "Political Liberalization, Gender, and the State," in Political Liberalization and Democratization in the Arab World, ed. Rex Brynen, et al. (Boulder, Colo: Lynne Rienner, 1995), 187-208. 4. Munira A. Fakhro, "Gender, Politics and the State in the Gulf Region," Middle East Policy 5, no.3 (1997):166-70.

5. Val Moghadam, Modernizing Women: Gender and Social Change in the Middle East (Boulder, Colo.: Lynne Rienner, 1993).

6. Ayse Kudat and Helen Abadzi. Women's Presence in Arab Higher Education: Linking School, Labor Markets and Social Roles, Economic Development Institute (EDI) Working Papers 870/005 (Washington, D.C.: World Bank, 1990).

7. M'hammed Sabour, Homo Academicus Arabicus, Publications in Social Sciences no. 11. (Joensuu, Finland: University of Joensuu, 1988), 95-98.

8. M'hammed Sabour, "Women in the Moroccan Academic Field: Respectability and Power," Mediterranean Fournal of Educational Studies 1, no. 1 (1996): 82.

9. Sabour, Homo Academicus Arabicus. 